\title{
TAREKAT QADIRIYAH WA NAQSABANDIYAH TERHADAP KESALEHAN SOSIAL MASYARAKAT DUSUN GEMUTRI SUKOHARJO SLEMAN
}

\author{
Siswoyo Aris Munandar ${ }^{\mathrm{a}, 1, *}$, Sigit Susanto ${ }^{\mathrm{b}, 2^{*}}$, Wahyu Nugroho ${ }^{\mathrm{c}, 3^{*}}$ \\ a Sekolah Tinggi Agama Islam Sunan Pandanaran, Yogyakarta, 55581, Indonesia \\ ${ }^{b}$ Sekolah Tinggi Agama Islam Sunan Pandanaran, Yogyakarta, 55581, Indonesia \\ ${ }^{c}$ Universitas Kristen Duta Wacana, Yogyakarta, 55224, Indonesia \\ ${ }^{1}$ siswoyoaris31@gmail.com*; ${ }^{*}$ sigitsusanto1@gmail.com*; ${ }^{3}$ wahyu_nugroho@staff.ukdw.ac.id*;
}

ARTICLE INFO

Article history:

Received : 2020-02-08

Revised : 2020-05-04

Accepted : 2020-06-01

Keywords:

Thariqah

Qadiriyah and Naqsabandiyah

Social Religiosity
Tarekat

Qadiriyah wa Naqsabandiyah

Kesalehan Sosial
Kata kunci:

\section{ABSTRACT}

This study was based on a case study on the era challenges that began to erode spiritual and social aspects of the society. Sufism through thariqah offers an increase in morality lethics. Thariqah was believed as one of media for social change in boosting morality / ethics. The main reason that thariqah as one of media for social change was that thariqah taught the improvement and burdened of individual morals. The research questions were: (1) what is the role of Qadiriyah and Naqsabandiyah thariqahs in people's spiritual life? (2) what is the role of Qadiriyah and Naqsabandiyah thariqahs in maintaining the people's social religiosity? The study used field research, namely by digging field data and observing directly. The purpose of this study was to describe the role of Qadiriyah and Naqsabandiyah Thariqah on the people's social religiosity of Gemutri villagers. The findings revealed that the role of thariqah was to promote spirituality, and to teach noble morals. Increasing spirituality and moral teaching made Gemutri residents as individuals who love each other, do good deeds, be fair, maintain brotherhood, uphold the truth, and help each other. The individual character, according to Abdul Azhim, was the realm of social religiosity.

\section{ABSTRAK}

Penelitian ini berjudul "Tarekat Qadiriyah wa Naqsabandiyah terhadap Kesalehan Sosial Masyarakat Dusun Gemutri Sukoharjo Sleman". Latar belakang dari studi kasus ini adalah tantangan zaman yang mulai menggerus aspek spiritual dan sosial suatu masyarakat. Tasawuf melalui tarekat menawarkan peningkatan moralitas/etika. Tarekat dipercaya sebagai salah satu media perubahan sosial dalam mendongkrak peningkatan moralitas/etika. Alasan utama bahwa tarekat sebagai salah satu media perubahan sosial adalah di dalam tarekat mengajarkan peningkatan dan pembenahan moral individu. Diitinjau dari segi rumusan masalahnya dapat ditarik dua pertanyaan yakni, Pertama, bagaimana peranan tarekat Qadiriyah wa Naqsabandiyah terhadap kehidupan spiritual masyarakat?. Kedua bagaimana peran tarekat Qadiriyah wa Naqsabandiyah dalam menjaga kesalehan sosial masyarakat? Upaya menjawab permasalahan dalam penelitian ini maka digunakan metodologi penelitian lapangan (field research), yakni dengan menggali datadata lapangan dan mengobservasi secara langsung. Adapaun tujuan dari penelitian ini untuk mendeskripsikan peran Tarekat Qadiriyah 
wa Naqsabandiyah terhadap kesalehan sosial masyarakat Gemutri. Hasil dari penelitian ini menunjukkan peran tarekat yakni peningkatan spiritualitas, dan pengajaran akhlak mulia. Peningkatan spiritualitas dan pengajaran akhlak menjadikan warga Gemutri sebagai individu-individu yang menyayangi sesama, beramal saleh, berlaku adil, menjaga persaudaraan, menegakkan kebenaran, dan tolong menolong. Karakter individu tersebut menurut Abdul Azhim merupakan ranah dari kesalehan sosial.

\section{Pendahuluan}

Masyarakat modern dan zaman modern merupakan kelanjutan yang wajar dan logis dari perkembangan kehidupan manusia. Modernisasi dapat dipandang sebagai keharusan sejarah, namun tidak semuanya bernilai positif, dalam modernisasi terdapat berbagai problem yang menyertainya antaralain kapitalisme, materialisme, yang mengakibatkan kemunduran kepribadian dan pelunakan moral masyarakat (Madjid, 2019, hlm. 31). Dewasa ini manusia tumbuh seolaholah bertumpu pada kehidupan Barat (modernisasi dan westernisasi) yang mengagungkan akal pikiran dan kecanggihan teknologi (Yani, 1997). Manusia berkuasa atas alam kemudian memanfaatkan alam bagi kemajuan hidupnya. Sebenarnya paham ini sangat bertentangan dengan filsafat Timur yang menganggap bahwa manusia adalah sebagai microcosmos (jagat kecil) yang merupakan bagian dari macrocosmos (jagat besar) yakni alam semesta. Dampak buruk dari kebudayaan Barat menyebabkan konsumerisme, materialisme, hedonisme yang semakin menjamur di Indonesia dan negaranegara di dunia. Modernisasi menjadi tantangan tersendiri bagi masyarakat Indonesia untuk menyaring pengaruh positif dan negatif. Hal yang baik diterima, namun yang buruk dan merusak seharusnya ditinggalkan (Wahid, Amin, \& S. Ahmad, 1993, hlm. 14).

Semula banyak orang terpukau dengan modernisasi. Mereka menganggap modernisasi secara langsung akan membawa kesejahteraan. Namun mereka lupa dibalik modernisasi itu terdapat gejala buruk seperti kriminalitas tinggi, pemerkosaan, korupsi, kenakalan remaja, bunuh diri, prostitusi, gangguan jiwa dan lain sebagainya. Gejala tersebut merupakan dampak penyalahgunaan dari modernisasi yang tidak hanya merusak secara fisik namun juga merusak nilai-nilai kehidupan. Dampak di atas dipandang bahwa modernisasi telah gagal memberikan kehidupan yang lebih bermakna bagi manusia. Krisis akidah, degradasi moral menjadikan manusia merasa kering dan hampa. Mereka merasakan kesenangan yang kasat mata, namun disisi yang lain mereka kehilangan sesuatu yang besar (A. Syukur, 2001).

Globalisasi menimbulkan masalah besar, banyak orang terasingkan, terjadi krisis sosial, depresi, kekerasan sosial. Dampak tersebut memang bukan sepenuhnya bawaan globalisasi, hanya saja mentalitas masyarakat Indonesia yang masih tradisional dipaksa berubah harus menyesuaikan diri dengan peradaban modern. Arus globalisasi yang semakin menjamur berimbas pada pola pikir masyarakat. Masyarakat terjebak pada gairah dan kemegahan globalisasi. Mereka secara tidak sadar terjajah oleh ambisi-ambisi dunia yang besar. Akibatnya mereka kehilangan sisisisi keruhanian, mengalami krisis akidah, serta degradasi moral. Masyarakat semakin jauh dari nilai-nilai keluhuran Timur, norma-norma serta semakin jauh dari aturan-aturan adat.

Salah satu karakteristik dari tasawuf adalah peningkatan moralitas atau etika. Oleh karena itu, tasawuf mempunyai kaitan erat dengan teori dan nilai-nilai etika. Tasawuf menjadi jawaban atas kehampaan masyarakat modern yang terjebak di dalamnya. Moralitas atau etika mereka yang telah dirusak oleh modernisasi serta arus globalisasi akan diobati tasawuf. Etika mengajarkan manusia mempunyai tujuan luhur yaitu kebahagiaan di akhirat. Amal yang dipandang baik dapat menghasilkan pengaruh pada jiwanya yang membuatnya mengarah kepada tujuan tersebut. Mereka yang mengalami krisis akidah, degradasi moral, kemudian kondisi keruhaniannya akan dibangkitkan dengan tasawuf (H. M. A. Syukur, 2002, hlm. 16).

Tasawuf menawarkan peningkatan moralitas atau etika dapat didapatkan melalui tarekat-tarekat. Tarekat merupakan wadah tasawuf yang terlembagakan. Pada dasarnya tarekat mempunyai peran yang penting dalam kehidupan keberagamaan. Disisi lain tarekat 
dipercaya sebagai salah satu media perubahan sosial dalam mendongkrak peningkatan moralitas atau etika (Nurcholis, 2011). Alasan utama bahwa tarekat sebagai salah satu media perubahan sosial adalah di dalam tarekat mengajarkan peningkatan dan pembenahan moral individu. Dimulai dari pembenahan individu-individu kemudian dapat berpengaruh pada kehidupan sosial. Banyak tarekat-tarekat pada khususnya di Indonesia mempunyai peran penting dalam kehidupan sosial, sebagai contoh adalah pemberontakan petani di Banten (memberontak Belanda) kemudian penanganan korban madat di ponpes Suryalaya Tasikmalaya. Contoh tersebut merupakan salah satu peran tarekat dalam kehidupan sosial (H. M. A. Syukur, 2002, hlm. 26).

Tarekat yang merupakan organisasi yang lahir atas nama keagamaan juga mempunyai andil dalam berbagai bidang lain diantaranya: budaya, pendidikan dan pada bidang-bidang lain (Huda, 2007). Banyak peran-peran tarekat yang sebenarnya tidak melulu pada bidang keagamaan atau pada kebatinan (keimanan) saja melainkan merambah pada bidang-bidang lainnya. Seperti pendidikan, hubungan kemasyarakatan sebenarnya secara pelan telah menjadi objek pengaruh tarekat itu sendiri. Titik temu ini kemudian menjadi sebuah tujuan dan acauan bagaimana tarekat akan menanggapi gejala-gejala sosial kemasyarakatan ataupun masalah sosial di suatu tempat. Dalam hal ini dakwah dari tarekat secara pelan mempengaruhi sikap batin maupun perilaku masyarakat menuju suatu tatanan kesalehan individu dan kesalehan sosial, karena tarekat sebagai lembaga pendidikan yang membentuk karakter yang beradab (Sobary, 2007, hlm. 28).

Disisi lain tarekat digemari karena memiliki sesuatu yang unik. Bruinessen di dalam penelitiannya mengemukakan bahwa mayoritas masyarakat Indonesia tertarik pada bidang tarekat karena sisi mistik, praktek tasawuf dan latihannya. Orang-orang Indonesia sangat menyukai hal-hal yang bersifat mistik, apalagi orang-orang Jawa, oleh karena itu tarekat juga mempunyai pintu masuk tersendiri bagi masyarakat Indonesia. Terlepas dari hal di atas, masyarakat Indonesia tertarik mengikuti tarekat karena kepribadian sang guru tarekat (kiai, mursyid) yang sangat kharismatik. Faktanya kebanyakan para kiai yang mempunyai atau mengajarkan tarekat mempunyai lebih banyak pengikut dibanding para kiai yang tidak mengajarkan tarekat (Bruinessen, 1992).

Seiring dengan perkembangan zaman, muncul tarekat-tarekat yang sangat menjamur di dunia Islam. Indonesia sendiri mempunyai tarekat yang lahir dan asli dari masyarakat Indonesia, yaitu tarekat Qadiriyah wa Naqsabandiyah. Tarekat Qadiriyah wa Naqsabandiyah dalam sejarahnya adalah kombinasi dari tarekat Qadiriyah dan tarekat Naqsabandiyah. Kombinasi tarekat ini dirintis oleh Ahmad Khatib Sambas, seorang ulama dari Sambas Kalimantan Barat (Khaerani \& Nurlaen, 2019, hlm. 89). Pada awal pengembangan tarekat, Syekh Ahmad Sambas memperoleh pengikut terutama dari kalangan pelajar asal Nusantara yang menuntut ilmu agama di tanah suci. Kemudian atas dakwah mereka, tarekat Qadiriyah wa Naqsabandiyah dapat tersebar di Nusantara dan memperoleh banyak pengikut khususnya di pulau Jawa (Sujuthi, 2001).

Tarekat Qadiriyah wa Naqsabandiyah telah hadir di Dusun Gemutri sekitar tahun 1956 M. Tarekat ini dikenalkan oleh Kiai Asy'ari Hasyim atau biasa disebut Mbah Asy'ari. Awalnya Mbah Asy'ari mengajarkan syariat Islam kepada warga masyarakat yang masih awam. Dakwah tersebut kemudian berlanjut pada pengenalan tarekat Qadiriyah wa Naqsabandiyah. Salah satu hal yang sudah berhasil yakni merubah persepsi masyarakat melalui ajaran tarekat Qadiriyah wa Naqsabandiyyah, yang sampai saat ini setiap tahun selalu bertambah jumlah jamaahnya. Jamaah atau masyarakat yang mengikuti ajaran tarekat Qadiriyah wa Naqsabandiyyah ini sebagian besar adalah dari kalangan tua atau yang sudah berumah tangga. Lambat-laun eksistensi tarekat Qadiriyah wa Naqsabandiyah di Dusun Gemutri membawa dampak terhadap warga masyarakatnya, antara lain masyarakat telah melaksanakan salat lima waktu, berjamaah di masjid dan lain sebagainya. Jumlah pengikut tarekat Qadiriyah wa Naqsabandiyyah penduduk Dusun Gemutri Desa Sukoharjo adalah 825 jiwa yang terbagi dalam 350 Kepala Keluarga (KK) dan 6 Rukun Tangga (RT). Secara umum mata pencaharian warga Dusun Gemutri merupakan pekerja buruh serabutan, entah buruh tani, buruh bangunan, buruh pabrik, dan lain sebagainya. Prosentasenya adalah $80 \%$ sebagai buruh, $5 \%$ pedagang, $5 \%$ 
sebagai peternak, dan 10\% lain-lain (US, 2019).

Di sisi lain penulis melihat realita kehidupan masyarakat Dusun Gemutri yang masih peduli terhadap nilai dan norma-norma dalam kehidupan bermasyarakat. Masyarakat Gemutri mempunyai kepedulian sosial yang tinggi. Penulis beranggapan bahwa hal tersebut yang kemudian membuat penulis ingin mengetahui secara lebih mendalam. seberapa besar eksistensi tarekat Qadiriyah wa Naqsabandiyah di Dusun Gemutri Sukoharjo Sleman? Bagaiman dampaknya setelah adanya tarekat Qadiriyah wa Naqsabandiyah?

\section{Tinjauan Pustaka}

\section{a. Kesalehan Sosial}

Istilah "Kesalehan Sosial" berasal dari dua kata yakni "kesalehan" dan "sosial". Kesalehan berasal dari kata saleh yang mendapatkan awalan "ke" dan akhiran "an". Kata saleh mempunyai arti suci dan beriman atau taat serta sungguh-sungguh menjalankan ibadah (Pustaka, 2010, hlm. 32). Dalam AlQur'an kata saleh disebutkan sebanyak 124 kali dalam berbagai variasi makna, termasuk bentuk jamaknya shāliḥūn atau shälihāat. Satu di antaranya pada Q.S. al-Anbiya: 105, yang mengabarkan tentang keberadaan dan peran penting orang-orang saleh bagi kehidupan di muka bumi, "Dan sungguh telah Kami tulis di dalam Zabur bahwa bumi ini dititipkan kepada hamba-hamba-Ku yang saleh" (Cecep Zakarias El Bilad, t.t.).

Adapun kata sosial berasal dari kata Latin "socius" yang berarti kawan atau teman. Sosial dapat diartikan sebagai bentuk pertemanan atau perkawanan yang berada dalam skala besar yaitu masyarakat. Artinya sosial adalah segala sesuatu yang berhubungan dengan masyarakat atau kemasyarakatan. Kata kesalehan dan sosial memiliki arti yang lebih luas. Berikut beberapa pendapat tokoh tentang definisi dari Kesalehan Sosial (Firdaus, 2017). Pertama, menurut Bisri "Kesalehan sosial merupakan perilaku orang-orang yang sangat peduli dengan nilai-nilai Islam, yang bersifat sosial. Suka memikirkan dan santun kepada orang lain serta suka menolong, dan seterusnya: meskipun orang-orang ini tidak setekun kelompok kesalehan ritual dalam melakukan ibadat seperti sembahyang dan sebagainya itu". Kedua, menurut Kahmad "Kesalehan sosial adalah aktualisasi atau perwujudan iman dalam praktis kehidupan sosial". Ketiga, menurut Susilaningsih "Kesalehan Sosial" merupakan religiusitas atau bisa disebut dengan rasa agama sebagai kristal nilai agama (religious conscience) dalam diri yang terdalam dari seseorang yang merupakan produk internalisasi nilai-nilai agama yang dirancang oleh lingkungannya" (Abdullah \& Abdurahman, 2006, hlm. 25).

Kesalehan sosial merupakan perihal sosial yang berkaitan dengan ibadah. Ibadah dapat dibedakan menjadi dua, yaitu ibadah secara khusus dan ibadah secara sosial. Ibadah secara khusus kemudian dikenal sebagai kesalehan ritualistik, sedangkan secara sosial dikenal sebagai kesalehan sosial. Kesalehan sosial ini ditujukan kepada manusia lainnya dan bersifat global (Sobary, 2007). Kesalehan sosial menunjukkan bagaimana kita harus berhubungan dengan orang lain atau masyarakat lain sesuai ajaran Islam. Kesalehan sosial dapat dipahami suatu bentuk kesalehan dalam bermasyarakat, dan tidak hanya untuk diri sendiri. Sering kita dengar dari kalangan Muslim banyak orang yang mempertentangkan antara kesalehan individual dan kesalehan sosial.

Sebagian masyarakat sering menjumpai ketimpangan yang tajam antara kesalehan sosial dan kesalehan individual. Banyak orang yang saleh secara individual, namun tidak atau kurang saleh secara sosial. Kesalehan yang dilakoni untuk dirinya sendiri merupakan kesalehan ritualistik, karena mementingkan ibadah ritual saja seperti, salat, zikir, puasa, haji, dan seterusnya. Disebut kesalehan individual karena semata-mata hanya mementingkan aspek ibadah yang berhubungan dengan Tuhan dan kepentingan diri sendiri. Sementara pada saat yang sama mereka tidak memiliki kepekaan sosial, dan kurang menerapkan nilai-nilai Islami dalam kehidupan bermasyarakat. Kesalehan ini ditentukan berdasarkan ukuran serba formal, yang hanya mementingkan hablum minallah, dan tidak disertai hablum minan nas (Helmiati, t.t.).

Kriteria Kesalehan seseorang tidak hanya diukur dari ibadah ritual salatnya dan puasanya, namun juga dilihat dari sisi perilaku sosialnya. Sebuah hadis dikisahkan, 
bahwa suatu ketika Nabi Muhammad SAW mendengar berita tentang seorang yang rajin salat di malam hari dan puasa di siang hari, tetapi lidahnya menyakiti tetangganya. Kemudian Nabi berkomentar: "Ia di neraka". Hadis ini memperlihatkan kepada kita bahwa ibadah ritual saja belum cukup. Ibadah ritual mesti dibarengi dengan kesalehan sosial. Kemudian dalam hadis lain diceritakan, bahwa ada seorang sahabat pernah memuji kesalehan orang lain di depan Nabi SAW. Nabi bertanya, "Mengapa ia kau sebut sangat saleh?". Sahabat itu menjawab, "Soalnya, tiap saya masuk masjid ini dia sudah salat dengan khusyuk dan tiap saya sudah pulang, dia masih saja khusyuk berdoa." "Lalu siapa yang memberinya makan dan minum?" Tanya Nabi lagi. "Kakaknya," jawab sahabat tersebut. Lalu kata Nabi, "Kakaknya itulah yang layak disebut saleh".

Masyarakat yang ideal seharusnya mempunyai dua aspek kesalehan tersebut, jika hanya memiliki salah satu aspek kesalehan maka masyarakat tersebut dapat dikatakan masyarakat yang tidak unggul. Contoh masyarakat atau seseorang yang mementingkan kesalehan ritualistiknya tapi meninggalkan kesalehan sosial, maka seseorang tersebut akan gagal di masyarakat, sebaliknya masyarakat atau seseorang yang menjalankan kesalehan sosial tapi melalaikan kesalehan ritualistik maka akan sia-sia, seseorang tersebut akan berguna bagi masyarakat tapi sebenarnya manfaatnya hanya sebatas luarnya saja. Masyarakat yang melalaikan kesalehan ritualistik dapat dikatakan bahwa kesalehan sosialnya hanya semata-mata mencari hal-hal yang materalistik karena kesalehan sosial yang benar saleh adalah yang tidak meninggalkan aspek ritual, karena kesalehan ini sangat erat hubungannya dengan ritualistik (Bisri, 1994, hlm. 29).

\section{b. Bentuk-Bentuk Kesalehan Sosial}

Kesalehan sosial mempunyai cakupan yang sangat luas karena semua aspek yang berkembang dalam masyarakat dapat menjadi bagian dari masalah sosial. Secara garis besar cakupan kesalehan sosial sejalan dengan perbaikan (islah) yang diupayakan melalui Al-Qur'ān. Adzim, upaya islah yang dilakukan Al-Qur'ān yang sejalan dengan cakupan kesalehan sosial dapat dinilai dari beberapa segi antara lain:
1. Kesalehan sosial dalam pemantapan akidah (islahul 'aqoid)

Al-Qur'ān sering menyandingkan kata iman dan amal saleh dalam satu kalimat. Hal ini menunjukkan bahwa kedua hal tersebut merupakan suatu kesatuan yang tidak dapat dipisahkan. Iman (kesalehan ritual) harus berimplikasi amal saleh. Sebaliknya, amal saleh harus dilandasi oleh akidah yang kokoh sehingga perjalanan dunia akhirat menjadi seimbang dan responsible.

2. Kesalehan sosial dalam pemantapan ibadah (islahul 'ibadah)

Kesalehan seseorang dapat dilihat dari salatnya. Apabila salatnya telah sesuai dengan syariat Islam maka orang tersebut juga saleh secara sosial. Sebaliknya jika orang tersebut mengalami hambatan dalam kehidupan sosial, bisa jadi penyebabnya adalah terdapat kesalahan dalam salatnya. Kesalehan sosial erat kaitannya dengan pemantapan ibadah. Semakin Intensif ibadah seseorang, maka semakin saleh secara sosial (Firdaus, 2017).

3. Kesalehan sosial dalam pemantapan akhlak (islahul akhlak)

Umat Islam secara individu mempunyai potensi untuk melakukan perbaikan dan peningkatan ibadah. Ibadah tidak hanya mahdah, tetapi juga ghairu mahdhah seperti perbaikan akhlak. Potensi kesalehan sosial berbanding lurus dengan pemantapan akhlak secara sosial, keinginan untuk menjadi lebih baik dari hari sebelumya menjadikan optimalisasi pemantapan akhlak menjadi lebih besar (Falah, 2016).

4. Kesalehan sosial dalam kehidupan bermasyarakat (islahul ijtima')

Al-Qur'ān memberikan banyak seruan untuk melakukan kebaikan dalam kehidupan bermasyarakat. Seruan tersebut antar lain berlomba-lomba dalam kebaikan (fastabiqul khairaat), tolong menolong dalam kebaikan dan takwa (ta'awun 'ala al-birri wa attaqwa), silaturahmi dan berbagai norma sosial.

5. Kesalehan sosial dalam pemantapan politik (islahul siyasah)

Politik tidak dikesampingkan sebagai bagian penting dalam penerapan kesalehan sosial. Konsep musyawarah, demokrasi, hak asasi manusia dan keadilan menjadi sangat penting bagi penerapan kehidupan politik yang saleh. Intervensi kesalehan dalam 
cakupan politik membuktikan bahwa politik tidak selamanya buruk, tapi dapat ditata sesuai koridor yang telah digambarkan melalui dalil-dalil Al-Qur'ān dan Sunnah.

6. Kesalehan sosial dalam kehidupan ekonomi (islahul mal)

Proses mendapatkan dan menggunakan harta perlu memperhatikan aspek hak orang lain. Harta yang telah dimiliki ada bagian yang harus dikeluarkan seperti zakat, ataupun yang tidak wajib seperti infaq, sedekah, wakaf. Kesalehan sosial juga ditopang untuk menghindari hal-hal tercela seperti, riba, korupsi, kolusi, khianat, dzalim atau penipuan.

7. Kesalehan sosial dalam kedudukan wanita (islahul nisa)

Wanita ditempatkan dalam posisi terhormat dalam Islam. Al-Qur'ān juga memberikan konsep mengenai kesetaraan gender, perlindungan hak, martabat dan kehormatan wanita.

8. Kesalehan sosial dalam perdamaian dunia (islahul jaryi)

Kesalehan sosial dalam bagian dari perdamaian dunia dapat dilakukan dengan cara mencintai tanah air, merawat alam semesta, dan menghargai perjanjian yang dibuat dalam hubungan dengan negara lain (Firdaus, 2017).

Cakupan kesalehan sosial yang telah dipaparkan oleh Adzim di atas dapat menentukan bentuk-bentuk kesalehan sosial. Bentuk-bentuk kesalehan sosial merupakan cerminan dari akhlak Islam sosial atau perilaku sosial Islami. Perilaku sosial Islami adalah perilaku masyarakat yang sesuai dengan syari'at dan ajaran Islam. Masyarakat yang tercermin kesalehan sosialnya dapat dilihat sebagai masyarakat yang tolong menolong, saling menyayangi, menghormati sesama, menjaga persaudaraan, berlaku adil, beramal sholeh, menegakkan kebenaran, tidak main hakim sendiri dan bermusyararah untuk mufakat (Srijanti, S.K, \& Pramono, 2009, hlm. 36).

\section{Metodologi Penelitian}

Metode penelitian merupakan langkah penulis untuk mengumpulkan informasi dan data. Metode penelitian berguna untuk memberikan gambaran penelitian yang meliputi prosedur penelitian, sumber data, analisis dan lain sebagainya (Sugiyono, 2008).

Penelitian ini berusaha untuk mendeskripsikan peran tarekat Qadiriyah wa Naqsabandiyah terhadap kesalehan sosial masyarakat Dusun Gemutri. Penelitian ini adalah penelitian lapangan (field research), yaitu penelitian yang dilakukan di lapangan guna mendapatkan data yang diperlukan (Azwar, 1998, hlm. 34). Berangkat dari objek penelitian serta latar belakang masalah yang diangkat dari penelitian ini maka jenis penelitian yang penulis gunakan adalah jenis penelitian kualitatif. Penelitian kualitatif adalah penelitian yang didasarkan oleh suatu kajian objek tertentu guna mengungkapkan masalah secara gamblang terhadap fenomena keadaan yang diteliti tanpa mempengaruhi objek kajian penelitian (S. Margono, 2005).

Jenis penelitian kualitatif sangat tepat karena objek kaitannya menyangkut manusia dan kehidupannya (sosial). Jika penelitian kuantitatif mengukur objek dengan suatu perhitungan, dengan angka, dengan prosentase serta statistik (berhubungan dengan exact) (Afifuddin \& Saebani, 2012, hlm. 25), penelitian kualitatif lebih menekankan pada segi kualitas secara alamiyah karena menyangkut sebuah pengertian, konsep, nilai, serta ciri-ciri yang melekat pada objek penelitian. Peneliti menggunakan penelitian kualitatif bertujuan untuk mengetahui lebih dalam tentang fenomena yang diteliti dan menjaga keaslian hasil penelitian (Koentjaraningrat, 1987).

Pendekatan dalam penelitian ini untuk memperoleh penjelasan tentang bagaimana eksistensi tarekat ini adalah pendekatan antropologi yakni pendekatan yang menggunakan nilai-nilai yang mendasari perilaku sosial masyarakat, status sosial, pola hidup dan lain sebagainya (Kaelan, 2010, hlm. 28). Melalui pendekatan ini diharapkan dapat menghasilkan sebuah penjelasan yang mampu mengungkap gejala-gejala dari suatu peristiwa yang berkaitan erat dengan tempat, lingkungan dan kebudayaan dimana peristiwa itu terjadi, kemudian dapat dijelaskan asalusul dan segi dinamika sosial dalam masyarakat dan pendapat tokoh-tokoh ulama serta jamaah dan mursyidnya (Suyanto \& Sutinah, 2015).

Adapun pengumpulan data untuk memperoleh data yang valid dan akurat. 
Penelitian ini menggunakan observasi, wawancara dan dokumentasi sebagai teknik pengumpulan data. Pertama, Observasi. Observasi adalah proses pengamatan terhadap suatu objek kajian. Dalam melakukan observasi seorang peneliti harus bersikap objektif tanpa mengada-ada ataupun mengurang dan menambah suatu pengamatan lapangan. Keterampilan mengobservasi sangat tergantung pada kemampuan merumuskan pertanyaan yang dibimbing oleh masalah dan tujuan penelitian. Laporan lapangan adalah dalam bentuk deskripsi yang didasarkan atas jawaban pertanyaan yang lahir dari pikiran peneliti dalam menghadapi dunia kenyataan. Jenis observasi yang digunakan adalah observasi partisipatif, yaitu penelitian yang terlibat dengan kegiatankegiatan yang sedang diamati dan digunakan sebagai sumber data penelitian. Metode observasi digunakan untuk mengumpulkan data dan mengamati perilaku sehari-hari masyarakat Dusun Gemutri.

Kedua, Wawancara. Dalam wawancara yang perlu diperhatikan adalah kualitas responden tersebut. Syarat lain bagi seorang responden atau informan adalah seorang informan harus bisa memberi informasi yang dapat dipercaya kebenaran dan akurasinya, serta mempunyai pengetahuan dan pengalaman dalam bidang yang menjadi bahan penelitian. Wawancara dilakukan kepada jamaah Tarekat Qadiriyah wa Naqsabandiyah, pengurus (mursyid/wakil) Tarekat Qadiriyah wa Naqsabandiyah, tokoh agama dan sebagian masyarakat Dusun Gemutri. Pihak-pihak yang penulis ambil sebagai informan antara lain, Kiai Uvis Syahrizal sebagai pengurus Tarekat Qadiriyah wa Naqsabandiyah Dusun Gemutri, Mbah Umar sebagai salah satu tokoh agama Dusun Gemutri, Bapak Bagyo sebagai Kepala Dusun Gemutri dan jamaah Tarekat Qadiriyah wa Naqsabandiyah Dusun Gemutri, Haji Harmo, Bapak Suwarno sebagai jamaah Tarekat Qadiriyah wa Naqsabandiyah Dusun Gemutri, Ahmad Faqih, Okki sebagai pemuda Dusun Gemutri, Ibu Ndari sebagai warga Dusun Gemutri.

Ketiga, Dokumentasi adalah penggalian data dengan mengumpulkan naskah atau dokumen. Dokumentasi bertujuan untuk mendapatkan data dalam menunjang analisis data primer. Teknik pengumpulan data dengan dokumentasi secara jelas memerlukan dokumen atau naskah-naskah. Dokumen merupakan catatan peristiwa yang telah lalu bisa berupa tulisan, gambar atau karya menumental seseorang. Di dalam dokumen biasanya terdapat pengetahuan yang relevan dan penting bagi tercapainya tujuan penelitian.

\section{Hasil dan Diskusi}

\section{a. Kondisi Masyarakat Gemutri Sebelum Kehadiran Tarekat Qadiriyah wa Naqsabandiyah}

Masyarakat Jawa diketahui kental akan budaya animisme (kepercayaan terhadap roh) dan dinamisme (dalam kaitan agama dan kepercayaan) yang melekat hampir di seluruh Jawa. Banyak perjalanan, kontribusi ulama dahulu seperti walisongo, pengaruh zaman dan faktor lain hingga sampai pada kondisi sosial keagamaan hingga sekarang ini. Perlu diketahui bahwa pengaruh dakwah walisongo sampai ulama-ulama abad ke-18 tidak serta merta menghapus tradisi masyarakat yang kental akan budaya animisme dan dinamisme. Pada tahun 90-an tidak sedikit masyarakat yang masih melakoni tradisitradisi tersebut walaupun sebenarnya mereka telah menganut Islam dan menjalankan syariatnya. Kesalahannya adalah kebanyakan dari masyarakat waktu itu menganut Islam hanya sebatas ritual yang belum didalami secara keseluruhan.

Contohnya waktu itu seseorang sudah melaksanakan salat secara rutin, tetapi suatu ketika juga pergi menemui dukun untuk meminta bantuan. Maka di sini tasawuf (salah satunya melalui tarekat) perlu hadir untuk memberi pemahaman kepada masyarakat agar mereka tidak hanya melakuan ritual syariat tanpa didasari pemahaman dan keimanan yang kuat. Tarekat serasa mampu menyikapi kondisi sosial keagamaan ini dengan amalanamalannya agar tidak melenceng dengan khittah Islam. Tarekat melalui pengajarannya memberi pemahaman mendalam tentang ajaran Islam.

Kondisi sosial ini mengantarkan Kiai Hasyim mengutus Mbah Asy'ari untuk menetap di Dusun Gemutri. Kiai Hasyim mengetahui Dusun Gemutri dan sekitarnya tidak ada apa-apa. Merupakan daerah yang tidak terurus, tidak terjamah oleh ulama, masyarakatnya awam. Mulanya Kiai Hasyim 
membeli sebidang tanah di Dusun Gemutri. Sebidang tanah tersebut kemudian oleh beliau didirikan masjid. Alasannya sangat sederhana karena di Dusun Gemutri dan sekitarnya belum ada masjid sama sekali (US, 2019). Kemudian Mbah Asy'ari diberi amanah masjid tersebut guna sebagai fasilitas penunjang dakwah beliau. Masjid ini diberi nama Ushuluddin, tentang seluk beluk nama ini penulis belum dapat informasi yang akurat. Intinya saat itu Masjid Ushuluddin adalah satu-satunya masjid di daerah tersebut.

Dakwah Mbah Asy'ari tidak berjalan mulus, banyak resiko dan tantangan yang harus beliau hadapi, terlebih masyarakat Dusun Gemutri tergolong awam dan belum mengenal salat. Mula-mula beliau mengajarkan salat fardhu, mengajak warga untuk ke masjid, tentu ini merupakan tantangan yang berat. Masyarakat pada waktu itu masih sangat awam, sulit sekali untuk mengajak mereka menunaikan salat, namun beliau tidak menyerah. Sampai-sampai hanya untuk membujuk masyarakat agar mau salat saja itu sangat sulit. Berkat ketekunan dan kesabaran Mbah Asy'ari kemudian satupersatu warga mulai mau salat dan pergi ke masjid. Pada waktu itu Mbah Asy'ari mempunyai misi agar masyarakat Dusun Gemutri mau salat dan pergi ke masjid, untuk bisa ngaji beliau berharap bisa dicapai pada generasi atau periode selanjutnya.

Mbah Asy'ari menetap di Gemutri pada tahun 1956 M, kemudian berdakwah kepada warga tetangga Dusun Gemutri yang belum terjamah oleh ulama. Warga diluar dusun pun banyak belajar agama kepada beliau. Setelah masyarakat Dusun Gemutri dan sekitarnya telah sedikit banyak mengetahui ajaran Islam beliau kemudian berdakwah ke timur (daerah Klaten). Mbah Asy'ari melihat di daerah Timur belum tersentuh ulama. Pada waktu itu wilayah selatan telah terjamah oleh kiai dari Krapyak, kemudian di wilayah bagian barat dan utara telah ada K.H. Mufid Mas'ud Pandanaran yang mendakwahkan Islam di sana (US, 2019).

Perjuangan pembinaan keagamaan Mbah Asy'ari tidak sekedar mengajari dan mengajak orang awam yang sangat kolot saja. Tantangan berat muncul ketika dakwah di Klaten, yakni Partai Komunis Indonesia (PKI). Klaten (Manisrenggo, Kemasan, Karanganom) merupakan salah satu daerah yang banyak PKI-nya. PKI merupakan organisasi yang identik tidak beragama, pemberontakan dan ingin memecah NKRI. PKI jelas tidak menyukai kiai dan dakwahnya yang notabene cinta tanah air, cinta perdamaian. Sebab itu zaman dulu banyak kiai yang diculik dan dibunuh oleh PKI. Ketika berdakwah di Klaten Mbah Asy'ari mendapat berbagai ancaman dan tekanan dari PKI. Awalnya beliau dakwah ke Klaten dengan berjalan kaki bersama lima orang pendereknya dari Dusun Gemutri. Beliau tidak takut jika ditengah perjalanan dihadang dan diculik oleh anggota PKI, beliau pasrah dan menggantungkan semua hidupnya pada Allah SWT. Kemudian setelah beberapa waktu Mbah Asy'ari mempunyai sepeda Onthel, selanjutnya beliau menggunakan sepeda tersebut untuk berdakwah di Klaten. Pernah suatu waktu sepeda beliau di rampok oleh PKI, namun keesokan harinya sepeda tersebut dikembalikan di depan rumah beliau.

Anggota PKI pernah membakar rumah dimana Mbah Asy'ari sedang mengulang ngaji. Saat itu beliau dan jamaahnya selamat. Banyak sekali ancaman dan resiko yang harus di ambil Mbah Asy'ari dalam melakukan dakwahnya, beliau dan pendereknya diancam akan dibunuh. Puncaknya adalah ketika beliau mendapat ancaman pembunuhan dari PKI. Mbah Asy'ari pun tak gentar dan tetap berdakwah di daerah tersebut, namun naas salah satu penderek Mbah Asy'ari setelah mengantar beliau ngaji telah hilang sampai sekarang tidak diketemukan, menurut cerita, penderek tersebut telah diculik PKI dan kemungkinan telah dibunuh.

Perjalanan dakwah Mbah Asy'ari sangat luar biasa, beliau sebagai orang berilmu rela menanggung resiko tinggi untuk membagikan ilmu yang telah ditimba agar masyarakat menjadi paham bagaimana ajaran Islam yang khittah. Kemudian setelah mulai banyak warga mampu menjalankan syariat Islam beliau mengenalkan tarekat, melalui tarekat seseorang tidak hanya sekedar beribadah ritual saja, tapi juga diasah batinnya.

Pengenalan tarekat ini diawali ketika Mbah Asy'ari mencontohkan wiridnya, kemudian banyak jamaahnya bertanya tentang wirid tersebut. Mbah Asy'ari kemudian mengatakan bahwa jikalau ingin 
tahu besok akan aku ajari dirumahku. Karena perkataan tersebut banyak jamaah beliau kemudian memasuki tarekat. Para jamaah yang masuk tarekat pun semakin banyak. Namun tidak semua orang tertarik akan tarekat (US, 2019).

Peran tarekat erat kaitannya dengan kiprah Mbah Asy'ari. Beliau merupakan orang yang bersih dan kharismatik. Kharismatik beliau tidak lain karena perilaku dan kedalaman ilmunya. Mbah Asy'ari memang tidak memiliki pesantren, namun para warga masyarakat dan para murid beliau sampai-sampai mengaku santri. Mbah Asy'ari kiai mereka yang paling berjasa, selain itu Mbah Asy'ari juga seorang mursyid diyakini masyarakat sekitar mempunyai otoritas yang besar dan kharismatik yang luar biasa. Hal ini muncul tidak lain karena masyarakat menganggap beliau merupakan orang suci yang dianugerahi berkah. Kepemimpinannya diakui secara umum karena seorang mursyid dan kiai yang mengorientasikan dirinya pada kepemimpinan umat. Dengan begitu hubungannya dengan masyarakat akan sangat intim secara emosional, sehingga apa yang beliau sarankan atau perintahkan akan sangat diperhitungkan di dalam masyarakat (Sukamto, 1999, hlm. 38).

b. Kondisi Masyarakat Gemutri Setelah Kehadiran Tarekat Qadiriyah wa Naqsabandiyah

Kehidupan sosial dan keagamaan di Dusun Gemutri jelas menunjukkan hasil yang baik. Sebelum tarekat yang dibawa Mbah Asy'ari ini masuk di Dusun Gemutri banyak warga yang belum menjalankan syari'at Islam, diantaranya tidak salat, puasa dan menjalankan kewajiban-kewajiban Muslim lainnya. Selain itu warga masih banyak yang berjudi, datang ke dukun, datang ke tempattempat keramat dan sebagainya. Kedatangan tarekat ini yang dibawa oleh Mbah Asy'ari secara perlahan mengubah perilaku masyarakat Dusun Gemutri. Masyarakat mulai mengenal salat, rajin ke masjid dan meninggalkan kebiasaan-kebiasaan buruk mereka.

Masyarakat Dusun Gemutri memberikan tanggapan positif atas kedatangan tarekat Qadiriyah wa Naqsabandiyah yang dibawa oleh Mbah Asy'ari, bahkan kebanyakan dari warga menganggap mereka adalah santri dari
Mbah Asy'ari. Klaim tersebut tidak lain karena masyarakat sangat menghormati Mbah Asy'ari walaupun beliau sendiri tidak mempunyai pesantren. Masyarakat Dusun Gemutri selanjutnya menjadi masyarakat yang saleh dan taat beribadah. Dapat disimpulkan pada proses awalnya adalah membina masyarakat Dusun Gemutri agar saleh secara individual. Saleh secara individual dimaksudkan agar masyarakat rajin beribadah dan menjalankan syariat Islam yang dicontohkan oleh Rasulullah. Tanggapan positif ini kemudian dapat dikaji lebih detail terkait dengan tarekat Qadiriyah wa Naqsabandiyah terhadap warga masyarakat Dusun Gemutri (AF, 2019).

1. Kesalehan Warga

Kesalehan secara umum mempunyai dua lingkupan, yakni hablum minallah dan hablum minan nas. Hablum minallah atau biasa disebut kesalehan individual adalah kesalehan seseorang pada ruang lingkup ritual. Dalam kehidupan sehari-hari terkadang kita melihat ketimpangan antara kesalehan individual dengan kesalehan sosial. Sebenarnya di dalam Islam kedua corak kesalehan tersebut merupakan suatu kesatuan. Namun, ada sebagian orang yang saleh secara individual namun kurang dalam sosial. Bagi penulis orang yang saleh secara individual namun kurang saleh pada sosial merupakan orang yang hanya menggeluti Islam sebatas kulit luarnya saja, mereka belum menjamah bagian dalam.

Kesalehan tidak hanya diukur dari segi ibadah saja, tetapi juga diukur dari perilaku sosialnya. Tarekat sebagai organisasi tasawuf mempunyai tanggung jawab terhadap umat terutama para jamaahnya. Tarekat Qadiriyah wa Naqsabandiyah di Dusun Gemutri melakukan pembinaan kepada masyarakat salah satunya dengan pengajian-pengajian yang rutin dibina oleh mursyid dan para wakilnya. Adanya pengajian tersebut berdampak pada spiritualitas warga mengalami peningkatan. Mereka tersadar akan makna hidup yang sebenarnya, hidup mereka lebih nyaman dan sejahtera.

Ajaran tarekat Qadiriyah wa Naqsabandiyah memiliki peran yang tinggi terhadap kesalehan dan makna hidup mereka. Seperti yang telah diungkapkan oleh Bapak Bagyo (52). Pak Bagyo sudah 10 tahun mengikuti Tarekat Qadiriyah wa Naqsabandiyah. Setelah tarekat ada di Dusun 
Gemutri para pengikutnya mengalami berbagai pengalaman batin tentang makna hidup. Mereka mendapatkan nasihat-nasihat, mengamalkan amalan-amalan (wirid) tarekat, kemudian diaplikasikan kedalam kehidupan sehari-hari. Kehidupan harus bermakna, pada hakikatnya bermaknanya kehidupan dapat dicapai dengan menjadi pribadi yang saleh, saling menghormati, saling menyayangi, membantu sesama, tidak memusuhi orang, tirakat dan selalu meningkatan kualitas hidup.

"Orang yang dekat dengan kiai akan enak hidupnya, akan tenang hatinya. Pokoknya apa yang telah diperintahkan kiai dilaksanakan dengan senang hati, maka InsyaAllah hidup kita tidak akan kurang. Kita tak perlu mengejar dunia, dunia itu tidak berarti, dunia akan datang sendiri ketika sudah ketemu jalannya. Memberi manfaat kepada sesama, orang yang paling baik adalah orang yang bermanfaat bagi orang lain. Menyayangi orang lain, jujur, tidak menyakiti orang lain, tidak dendam ketika disakiti orang lain dan selalu pasrah terhadap ketetapan Allah SWT. Dengan demikian hidup kita akan terasa indah, nyaman dan tenang, karena semua sudah ditanggung oleh Allah SWT, seorang hamba tidak perlu khawatir. Kita harus total percaya pada Allah, masalah sesulit apapun merupakan ujian dari Allah agar kita naik tingkat. Kita harus banyak-banyak mujahadah, dengan mujahadah nanti akan mucul keajaiban-keajaiban dari mujahadah tersebut" (B, 2019).

"yang saya rasakan pada perubahan hidup saya adalah tentang tawakkal, dulu kalau gagal panen saya begitu merasa sedih, namun saat ini ketika panen perasaan saya telah pasrah dan mensyukuri apa yang diberikan Tuhan, saya tidak tau pasti perubahan ini akibat dari sering ikut pengajian atau sebab lain yang jelas saya merasakan perubahan hidup ini" (MU, 2019).

Mbah Umar (78) adalah imam Masjid Ushuluddin dan ulama yang dituakan di Dusun Gemutri. Beliau merupakan murid dari Mbah Asy'ari. Diusianya yang sudah tua beliau secara istiqomah berjamaah di Masjid. Sebelum masuk tarekat, beliau menjalankan syariat Islam pada umumya. Namun setelah masuk tarekat beliau mampu merasakan bagaimana hidup yang sebenarnya. Hidup yang penuh dengan kepasrahan, hati yang lapang saling menyayangi dan yang paling utama adalah kenikmatan kedekatan dengan tuhan (MU, 2019).

Haji Harmo (56), seorang pengusaha yang mempunyai toko Bakpia Pathok di Jalan Mataram. Sebagai seorang pengusaha dirinya tak melulu memikirkan usahanya. Harta dunia dan sebagainya adalah titipan. Dirinya mempercayakan usahanya pada karyawannya, hanya sesekali melihat toko untuk membantu karyawannya. Haji Harmo mengungkapkan:

"seandainya saya gandrung dengan usaha maka saya tidak akan sempat untuk beribadah, mendekatkan diri dengan Allah, membaca Al-Quran dan lain-lain. Hidup telah dijamin oleh Allah, perihal dunia hanya pelengkap sahaja yang paling penting adalah kehidupan di akhirat nanti. Pemahaman hidup ini didapat dari Tarekat Qadiriyah wa Naqsabandiyah. Sebenarnya saya baru belajar Al-Quran pada tahun 2003, memang sangat terlambat diusia yang sudah usia kepala empat, namun berkat keuletan dan kerja keras akhirnya mampu membaca Al-Quran dengan fasih".

Hal yang luar biasa dialaminya adalah pernah bermimpi pergi ke makam Rasulullah, disana Haji Harmo menceritakan melihat Rasulullah sedang diajar ngaji oleh seseorang. Awalnya tidak percaya, karena Rasulullah adalah panutan tidak mungkin diajari oleh orang lain. Dirinya mengira mimpi itu datang dari setan, namun karena rasa penasarannya, maka dirinya pergi ke seorang kiai dan menanyakan perihal berikut, kemudian dijelaskan bahwa setan tidak mampu meniru rupa Rasulullah. Ketika seseorang bermimpi bertemu Rasulullah maka yang datang dalam mimpinya adalah Rasulullah sendiri. Sejak dari itu Haji Harmo sadar bahwa yang mengajari Rasulullah adalah Jibril. Untuk cerita lain dari mimpi tersebut dirahasiakan (BHH, 2019).

Bapak Suwarno (56) merupakan lelaki paruh baya yang ramah dan berhati baik. Sehari-hari dirinya bekerja sebagai buruh serabutan, yakni buruh bangunan ataupun buruh tani. Dirinya mengungkapkan bahwa peran dari tarekat Qadiriyah wa Naqsabandiyah yang dibawa oleh Mbah Asy'ari mempunyai arti penting dalam 
hidupnya dan kehidupan masyarakat Dusun Gemutri pada umumnya.

"Dulu, jika tidak ada Mbah Asy'ari mungkin sampai sekarang masyarakat di sini hanya sebatas Islam KTP saja. Peran beliau sangatlah besar, terutama dalam bidang keagamaan. Saya dulu juga merupakan murid dari Mbah Asy'ari. Setelah mengikuti tarekat saya mengalami perubahan besar. Hidup di dunia hanya sementara, akhiratlah yang paling penting. Memanfaatkan waktu semaksimal mungkin untuk beribadah dan mendekatkan diri kepada Allah SWT' (BS, 2019).

2. Pesan atau Doktrin dan Lingkungan

Tarekat Qadiriyah wa Naqsabandiyah secara halus telah mendoktrin warga Gemutri dan sekitarnya. Melalui pengajaran dan pembinaan, Tarekat Qadiriyah wa Naqsabandiah menyisipkan doktrin untuk selalu beramal saleh dan baik kepada sesama. Doktrin tersebut antara lain disisipkan dalam pengkajian kitab tasawuf seperti ihya ulumuddin, syarah hikam dan kitab lain saat dikaji pada tawajjuhan (menghadapkan diri dan membukatkan hati kepada Allah). Doktrin tersebut antaralain tentang membersihkan hati, dan menerangkan hubungan diri sendiri dengan orang lain maupun hubungan dengan makhluk lain. Lambat laun doktrin ini telah terwujud pada norma-norma sosial masyarakat Gemutri. Lingkungan juga merupakan faktor penentu tercapainya kesalehan sosial masyarakat Gemutri. Jika masyarakat berada pada lingkungan yang salah secara sadar atau tidak sadar maka lambat laun dia akan meniru atau menjadi seperti yang ada di lingkungannya. Dengan begitu, tarekat menciptakan kondisi lingkungan yang agamis dan kondusif.

Bapak Jumakir (47) adalah murid dari Mbah Asy'ari. Setelah menikah ia berdomisili di Pundong, Bantul. Ia hidup di lingkungan Muhammadiyah, yang tidak mengenal tahlilan. Kemudian ia mengajak warga sekitar untuk tahlilan, awalnya banyak mendapat penolakan namun akhirnya ajakannya diterima oleh masyarakat sekitar. Bapak Jumakir selalu mengajak kebaikan kepada sesama. Yang paling diingatnya adalah pesan dari Mbah Asy'ari untuk mengajarkan/membagi ilmu yang telah diperoleh kepada sesamanya, dengan tujuan kelak biasa berkumpul bersama-sama di akhirat nanti (B, 2019).

3. Menggiatkan Aktivitas Keagamaan

Tarekat Qadiriyah wa Naqsabandiyah di Dusun Gemutri telah giat melakukan kegiatan-kegiatan keagamaan. Kegiatan keagamaan tersebut disambut antusias masyarakatnya. Kegiatan keagamaan tersebut sedikit banyak berdampak pada kehidupan sosial masyarakat Dusun Gemutri. Dusun Gemutri mempunyai banyak kegiatan keagamaan seperti pengajian, mujahadah, tahlilan, pengajian kitab kuning dan lain sebagainya. Kegiatan keagamaan di Dusun Gemutri mempunyai dampak positif terhadap warga yakni, kesadaran sosial semakin meningkat, kepedulian warga tinggi, dan lain sebagainya. Dengan adanya kegiatankegiatan keagaman tersebut memberi dampak antara lain: Mendorong tingkat spiritualitas jamaah, mendorong keistiqomahan dalam beribadah, jamaah mampu menguasai konsep-konsep yang dibawa kiai dalam ceramahnya lalu mengaplikasikan kedalam kehidupan seharihari, jamaah lebih mengerti materi yang telah disampaikan dan jamaah mempunyai kepedulian sosial yang tinggi.

Ahmad Faqih (28) seorang mahasiswa pasca sarjana UIN Sunan Kalijaga dan guru di MA Sunan Pandanaran. Ahmad Faqih mengungkapkan bahwa peran dari tarekat Qadiriyah wa Naqsabandiyah yang dibawa oleh Mbah As'ari sangat besar, bahkan sebagian masyarakat mengaku bahwa mereka adalah santri beliau. Mereka enggan disebut murid, lebih pantas santri. Walaupun mereka tidak mondok tapi mereka adalah santri dari Mbah Asy'ari. Di Gemutri tidak ada pondok tapi ada kiai yakni Mbah Asy'ari. Karena Mbah Asy'ari wafat kemudian masyarakat menunjuk Kiai Uvis Syahrizal sebagai gantinya, karena beliau merupakan orang alim dan juga cucu dari Mbah Asy'ari. Berkat peran tarekat ini sekarang warga masyarakat Gemutri terutama golongan tua merupakan warga yang taat beribadah, masjidnya pun ramai jamaah. Struktur pengurus masjid jelas, kegiatan-kegiatan keagamaan di Dusun Gemutri bagus. Banyak kegiatan keagamaan di dusun ini. Namun kendalanya adalah golongan muda. Golongan muda di Dusun Gemutri kurang minat pada kegiatan keagamaan. Mereka aktif pada kegiatan-kegiatan sosial namun enggan untuk 
masuk ta'lim. Namun dalam hal ibadah mereka tidak meninggalkan kewajibannya hanya saja kurang minat dengan kegiatan keagamaan di Dusun Gemutri (AF, 2019).

\section{c. Dampak Kegiatan Tarekat dan Keagamaan Terhadap Kesalehan Sosial Masyarakat Dusun Gemutri}

Setiap ibadah baik mahdhah maupun ghairu mahdah akan memberi dampak sosial bagi para pelakunya. Dampak sosial tersebut dapat dilihat dari beberapa ayat dalam alQur'ān. Misalnya dalam ibadah salat, firman Allah swt

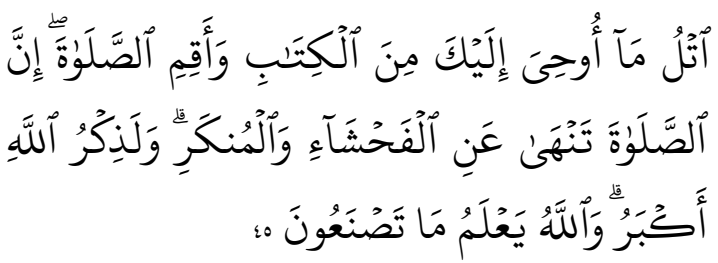

Artinya: Bacalah apa yang telah diwahyukan kepadamu, yaitu Al-Kitab (Al-Qur'an) dan dirikanlah shalat. Sesungguhnya shalat itu mencegah dari (perbuatan-perbuatan) keji dan mungkar. Dan sesungguhnya mengingat Allah (shalat) adalah lebih besar (keutamaannya dari ibadat-ibadat yang lain). Dan Allah mengetahui apa yang kamu kerjakan (Q.S. Al-Ankabut [29]:45)

Maka dapat disimpulkan bahwa ketika ada seseorang yang terlihat sangat rajin salat namun tidak berhasil mewujudkan implikasi sosial salat berupa pencegahan terhadap halhal keji dan mungkar, kemungkinan ada yang salah dengan salatnya. Contoh lain misalnya menunaikan ibadah haji yang punya implikasi sosial dengan gelar "haji mabrur", dalam pengertian orang yang naik haji seharusnya akan menimbulkan perubahan yang signifikan dalam intensitas ritual maupun perbaikan interaksi sosial dengan masyarakat. Apabila setelah melaksanakan haji hasilnya ternyata sebaliknya, seperti sombong dengan gelar hajinya, maka kemungkinan ada yang salah dengan ibadah hajinya (Firdaus, 2017). Dampak dari suatu ibadah akan berbeda-beda pada setiap pelakunya, tergantung kekhusyukan masingmasing individu. Adapun secara garis besar dampak kegiatan tarekat dan keagamaan di Dusun Gemutri dari hasil observasi, wawancara ataupun analisis antara lain sebagai berikut:

\section{Zikir}

Zikir merupakan sebuah kewajiban bagi para jamaah tarekat Qadiriyah wa Naqsabandiyah setelah seseorang di baiat karena ia telah terikat janji dengan guru mursyidnya maka ia mempunyai kewajiban dalam pengamalan zikir tarekat (Azlan, 2018). Zikir mempunyai banyak faedah di dalamnya, selain itu sorang mursyid selalu menekankan akan pentingnya zikir, akibat baik dari menjalankan zikir secara istiqomah, maupun akibat buruk ketika meninggalkan/lalai dalam zikir. Seorang murid yang meninggalkan zikir akibat lupa atau hal lain maka ia akan menggantinya di lain waktu. Kewajiban menjalankan zikir bagi para pengikut tarekat menjadikan seseorang istiqomah dalam berzikir. Keistiqomahan berzikir akan menciptakan peningkatan spiritual. Inti ajaran Tarekat Qadiriyah wa Naqsabandiyah adalah zikir, zikir pokok dilakukan setelah jamaah sholat wajib. Melalui zikir seorang murid diharapkan mendapatkan berbagai keutamaan di dalamnya (US, 2019).

a) Perbaikan moral/akhlak

Secara psikologis orang yang berzikir akan terbebas dari goncangan jiwa akibat depresi. Dengan banyak berdzikir superego yang ada pada diri seseorang akan berfungsi sebagai alat kontrol bagi perilaku baik, dengan berzikir seseorang akan tenang jiwanya sehingga sejahtera pula tingkah laku individu dan sosial. Seseorang yang terbiasa mengamalkan zikir akan menjadi pribadi yang taqwa dan senantiasa bertawakkal kepada Allah, ia akan menjadi pribadi yang qonaah. Ia merasa cukup atas segala pemberian Allah, dengan begitu ia mampu menahan hawa nafsu yang menjurus pada kerusakan moral/akhlak (Nihglatunnafi' Ah, 2006).

b) Terhindar dari perbuatan munkar

Hakikat zikir adalah ingat kepada Allah, dengan selalu ingat kepada Allah maka seseorang akan merasa terus diawasi. Zikir membuat seseorang merasa takut (khauf) kepada Allah sehingga sejak saat itu timbullah dalam diri seseorang usaha untuk menghindarkan diri dari segala macam pesona dan pengaruh dunia yang mampu menyebabkan lupa kepada Allah. Keadaan 
ini yang akan membuat seseorang terhindar dari perbuatan mungkar. Apabila seseorang akan melakukan maksiat/perbuatan munkar dan saat itu ia ingat kepada Allah maka ia akan beristighfar dan tidak melanjutkan untuk bertindak munkar. Setiap perbuatan munkar merupakan ketidakmampuan jiwa dalam mengendalikan akal pikiran yang dikendalikan oleh hawa nafsu. Orang yang terpedaya oleh hawa nafsu maka ia akan dengan mudah melakukan kemunkaran (US, 2019).

c) Mengembangkan sisi ruhaniyah

Zikir lataif (kelembutan) yang ada pada tubuh manusia mempengaruhi sisi ruhaniyah seseorang. Zikir lataif yang ditempatkan pada setiap titik kelembutan yang ada pada tubuh manusia akan diisi oleh zikir dan membersihkan dari kotoran hawa nafsu. Dengan bersihnya dari kotoran hawa nafsu maka seseorang akan dapat meningkatkan kesadaran spiritualitasnya, membuat kelembutan hati, dan mengembangkan ruhaniyahnya.

d) Ma'rifat

Zikir merupakan upaya untuk mendekatkan diri kepada Allah. Seseorang yang mengamalkan zikir dengan penuh ikhlas dan ketaatan kepada Allah, maka tidaklah mustahil akan dapat ma'rifat billah sehingga dapat diketahui segala rahasia dibalik tabir cahaya Allah dan Rasul-Nya secara jelas.

\section{Tawajjuhan}

Pertemuan tawajjuhan dimaksudkan sebagai sarana seorang murid untuk mendapat bimbingan sang mursyid. Peran mursyid sebagai pembimbing ruhani, agar hubungan mursyid dengan muridnya dapat berjalan terus, selain itu tawajjuhan dapat dimaksudkan agar seorang mursyid dapat mengetahui tingkatan spiritualitas muridnya. Murid yang akan berzikir diharuskan untuk membayangkan rupa mursyidnya atau dalam istilah tarekat Qadiriyah wa Naqsabandiyah disebut Rabitah. Rabitah ialah menghadirkan rupa guru ketika hendak berzikir. Hal ini merupakan salah satu dari kelanjutan ajaran yang terdapat pada tarekat ini yakni wasilah. Wasilah adalah mediasi melalui seorang pembimbing spiritual (mursyid) sebagai suatu hal yang dibutuhkan untuk kemajuan spiritual (Mulyati \& Bakhtiar, 2005). Melalui wawancara kepada Kiai Uvis Syahrizal dan analisa penulis bahwa tawajjuhan mempengaruhi kondisi spiritual antara lain:

a) Lebih dekat dengan Allah

Melalui tawajjuhan (terutama rabițah dan zikir) seorang murid secara emosional akan dekat dengan mursyidnya. Mursyid adalah orang yang 'alim dan telah terpilih atas tingkat spiritualnya, seseorang yang secara emosional (batiniyah) dekat dengan mursyid maka dirinya akan dekat dengan Tuhannya.

b) Memahami dan memasuki kondisi spiritual yang lebih tinggi

Kondisi spiritual merupakan kondisi yang sulit dinalar oleh akal pikiran. Seorang murid mendapatkan pengalaman-pengalaman spiritual yang sulit dinalar akal pikiran, untuk itu murid menceritakan pengalamannya kepada sang mursyid, kemudian mursyid memberi pemahaman perihal tersebut serta membimbingnya. Maka, seorang murid akan mampu memahami dan memasuki kondisi spiritual yang lebih tinggi karena bimbingan dari sang mursyid (US, 2019).

\section{Pengajian-Pengajian}

Pengajian mengusung pokok-pokok pembelajaran. Pokok-pokok pembelajaran tersebut antara lain perbaikan akhlak, ilmuilmu Islam (syari'at, tauhid dan tasawuf), upaya pendekatan terhadap Allah swt. Manusia merupakan makhluk Tuhan yang sering lalai dan iman yang sering naik turun. Atas dasar tersebut pengajian tidak hanya sebagai majelis untuk mendapatkan ilmu namun juga sebagai alarm ketika lalai. Dari hasil observasi dan wawancara memperlihatkan berbagai dampak pengajian terhadap kehidupan seseorang antara lain: Sebagai pengingat ketika lalai, sebagai pendongkrak keimanan, memotivasi pribadi untuk selalu sabar, syukur, tawakkal, ridha, dan qanaah, memerangi hawa nafsu dan membersihkan hati dari penyakit-penyakit hati.

Kegiatan tarekat Qadiriyah wa Naqsabandiyah menurut Kiai Uvis Syahrizal merupakan sarana sebagai peningkatan spiritualitas seorang hamba. Peningkatan spiritualitas ditandai dengan keridhaannya kepada Allah. Seorang hamba akan selalu tenang dan sabar ketika menjalani kehidupan. Seorang hamba yang telah mencapai kualitas ini akan selalu bersyukur dan melihat sisi baik dari segala ketetapan yang sudah ditentukan oleh Sang Khalik. Seorang hamba akan saling mengasihi satu sama lain, tidak 
iri atas pencapaian orang lain, sebaliknya turut merasakan senang atas pencapaian orang lain tersebut. Namun pencapaian dari kualitas ini tidak mudah didapat kecuali dengan pelatihan-pelatihan ruhani yang diajarkan dalam tarekat Qadiriyah wa Naqsabandiyah.

\section{d. Implementasi Nilai-Nilai Kesalehan Sosial Masyarakat Dusun Gemutri}

Agama tidak hanya dijadikan sebagai kepercayaan untuk menyembah Sang Pencipta, namun agama dianggap mampu menjawab masalah-masalah sosial kemasyarakatan yang tidak jarang membuat masyarakat bimbang dalam menentukan arah hidupnya. Manusia sebagai makhluk sosial akan membutuhkan satu sama lain untuk mempercayai dan menganut agama atau sekedar bertanya perihal kepercayaan yang dianutnya (Firdaus, 2017). Secara sederhana agama merupakan suatu kebutuhan. Kehadiran tarekat Qadiriyah wa Naqsabandiyah di Dusun Gemutri, merupakan salah satu kebutuhan pada sistem sosial masyarakat Gemutri. Pertumbuhan tarekat ini telah menempuh waktu puluhan tahun. Peran dari tarekat ini dapat dilihat dari kondisi sosial masyarakat Dusun Gemutri, dari aktivitas-aktivitasnya. Tarekat di sini juga dapat disebut sebagai organisasi, karena mereka tidak saja menjalankan kegiatan ritual keagamaan saja. Namun tarekat berhasil melakukan gerakan perubahan sosial dalam kehidupan masyarakat Dusun Gemutri. Gerakan sosial atau perubahan sosial tersebut dapat kita lihat dari perilaku masyarakat dan aktivitas yang terbentuk oleh warga dusun.

Selain itu kondisi sosial di pedesaan erat kaitannya dengan keagamaannya. Peran agama tidak mungkin dapat dipisahkan dari kehidupan masyarakat. Lain halnya masyarakat kota yang hubungannya dengan sisi keagamaan tidak terlalu dekat, karena masyarakat kota lebih tertarik akan sisi ekonomi yang bersifat individualis. Maka dari itu peran tarekat (yang diantaranya diwakili seorang mursyid sebagai pemuka agama dan pemimpin tarekat) sangat besar di dalam masyarakat.

Tarekat dari berbagai unsur di dalamnya (mursyid, kiai, amalan-amalan, kegiatankegiatan) secara jelas telah memperlihatkan peran yang dominan di dalam kehidupan masyarakat. Dengan peran semua element tarekat mempunyai andil penting dalam kehidupan masyarakat Dusun Gemutri. Masyarakat mampu merasakan perubahan dalam dirinya baik dari perilaku ataupun ibadahnya. Peletakan dasar norma-norma agamis telah tertanam sejak dulu di Dusun Gemutri.

Dengan adanya tarekat yang dibawa Mbah Asy'ari, spiritualitas masyarakat Dusun Gemutri kian meningkat, mereka tidak hanya menjalankan syariat saja namun mengamalkan ajaran Islam di kehidupan bermasyarakat. Dengan pengamalanpengamalan ajaran tarekat pengikutnya akan mendapat peningkatan secara spiritualitas. Masyarakat Dusun Gemutri menjadi masyarakat yang saleh dan taat beribadah. Keberhasilan sisi spiritual ini lambat laun menjadi karakteristik masyarakat Dusun Gemutri dan kemudian terbentuklah kesalehan sosial pada masyarakat Dusun Gemutri.

Konsep Malinowski yakni individu sebagai realitas psiko-biologis di dalam sebuah masyarakat (kebudayaan). Bagi Malinowski untuk memenuhi kebutuhan psiko-biologis individu dan menjaga kesinambungan hidup kelompok sosial dibutuhkan 7 kebutuhan pokok sebagai syarat keberlangsungan komunitas. Menurut Malinowski perilaku manusia diturunkan secara sosial antar generasi, lingkungan sosial merupakan faktor yang membentuk perilaku manusia (Marzali, 2014).

Hasil pengamatan dan observasi lapangan, penulis menemukan perilaku individu-individu terbentuk oleh lingkungan sosial yang sebagian besar merupakan peran dari tarekat Qadiriyah wa Naqsabandiyah. Peran tersebut antara lain membentuk individu yang saleh melalui kegiatankegiatan tarekat dan keagamaan yang dibina oleh tarekat Qadiriyah wa Naqsabandiyah di Dusun Gemutri. Guna mengetahui pencapaian dalam kesalehan sosial diperlukan sebuah indicator. Menurut Azhim indikator dari pencapaian kesalehan sosial yang tercantum dalam Tafsir Ruhul Bayan karya Ismail al-Buruswi minimal berupa: Tidak menyekutukan Allah, bekerja tanpa pamrih, bersih dari sikap riya, mengikuti jejak langkah Nabi, mengajak yang ma"ruf dan mencegah perbuatan munkar, hati yang terbuka untuk menerima kebenaran, lidahnya terjaga, memberi manfaat kepada sesama, 
mementingkan kepentingan orang lain, terbinanya ukhuwah Islamiyah, serta terwujudnya kesetiakawanan sosial berupa kasih sayang, ingin menolong dan saling memberi (Firdaus, 2017).

Indikator di atas menuntun penulis untuk melihat implikasi kesalehan sosial warga terhadap kegiatan kemasyarakatan. Kegiatan sosial merupakan bentuk realisasi atas nilainilai sosial masyarakat yang terbentuk secara bertahap dan menjadi suatu kebudayaan masyarakat Dusun Gemutri. Pertama adalah bersih dusun, warga dusun secara sadar dan bahu membahu melakukan kegiatan ini seminggu sekali yaitu pada hari Minggu. Kegiatan ini merupakan bentuk dari kesadaran masyarakat akan pentingnya solidaritas warga dusun untuk menciptakan lingkungan yang kondusif, nyaman dan sehat. Bersih dusun ini meliputi banyak kegiatan, seperti: membersihkan saluran air yang mampet, memperbaiki jalan dusun yang rusak, menyiapkan dusun ketika ada acara besar dan lain sebagainya. Kegiatan bersih dusun merupakan implemantasi dari kesalehan sosial yakni gotong-royong (B, 2019).

Kedua yakni tolong menolong, warga Dusun Gemutri sudah terbiasa untuk saling menolong, tidak hanya mendapat pertolongan atau memberi namun kedua-duanya tidak ditinggalkan. Ketika ada warga yang butuh bantuan maka warga lain akan senantiasa membantu. Warga Dusun Gemutri juga mempunyai empati tinggi, ketika ada warga yang sedang sakit maka warga lain saling berdatangan untuk menjenguk dan mendoakan warga yang sedang sakit agar segera sembuh. Adanya kas desa dan iuran insidental juga merupakan bentuk bantuan warga untuk menolong tetangga atau warga lain yang sedang terkena musibah.

"Warga Dusun Gemutri jika ada yang opname mengalami musibah akan membantu salah satu warga tersebut, bahkan sering warga Dusun Gemutri menggalang dana untuk membantu salah satu warga tersebut" (AF, 2019)

Ketiga yaitu menghormati sesama, warga Dusun Gemutri sangat menghormati antar warga. Di dusun ini hampir tidak ada kesenjangan sosial yang terlihat jelas. Antara si kaya dan si miskin tidak ada batas yang memisahkan, mereka tetap berinteraksi satu sama lain dengan biasa. Beda seperti daerah- daerah lain yang antara si kaya dan si miskin terdapat dinding tebal pemisah antara keduanya. Si kaya enggan menyambangi si miskin, dan si miskin yang merasa rendah diri ketika bertemu si kaya. Dengan begitu, akan terasa nyaman ketika jurang pemisah antara si kaya dan si miskin tidak pernah ada atau setidaknya tidak terlihat (B, 2019).

Keempat yakni beramal saleh, warga Dusun Gemutri merupakan warga yang umumnya berperilaku shaleh. Pandangan ini penulis keluarkan tidak lain setelah penulis berinteraksi langsung dengan masyarakat Dusun Gemutri dan selama penulis melakukan observasi. Kesalehan warga telah ditanamkan oleh Mbah Asy'ari yang berdakwah disana. Kesalehan ini tercermin dari perilaku warga, kesantunan, ketaatan dan keistiqomahan dalam beribadah. Namun untuk golongan pemuda sisi kesalehannya masih kurang. Golongan muda kurang berminat akan kegiatan religi. Salah satu faktornya adalah kesibukan (kuliah atau kerja), terkontaminasi kehidupan kota yang enggan terhadap agama. Di sini perlu digaris bawahi golongan pemuda Dusun Gemutri kurang berminat dengan kegiatan agama (pengajian dan lain-lain) namun untuk kegiatan sosial mereka antusias.

Kelima yakni musyawarah untuk mufakat, warga Dusun Gemutri sangat mengedepankan mufakat bersama. Musyawarah ini dilakukan agar tidak ada pemimpin atau perangkat desa berlaku otoriter, juga sebagai pemecahan masalah bersama. Musyawarah ini teraplikasikan dari berbagai rapat-rapat seperti, rapat RT, rapat $\mathrm{RW}$, rapat pemuda, rapat perangkat desa dan perkumpulan ibu-ibu PKK. Dengan adanya musyawarah maka ketika ada suatu permasalahan masyarakat mampu memecahkan permasalahan dengan bersamasama (B, 2019).

Kehidupan masyarakat seperti ini merupakan tatanan yang baik bagi perkembangan dan pertumbuhan dusun. Dengan kondisi seperti ini warga mempunyai kepedulian yang tinggi terhadap kehidupan sosial, maka mereka tidak hanya saleh secara individual tetapi saleh secara sosial pula.

\section{Kesimpulan}

Dari uraian di atas secara garis besar dapat ditarik benang merah sebagi berikut: 
Pertama. Latar belakang historis munculnya tarekat Qadiriyah wa Naqsabandiyah di Dusun Gemutri ketika Kiai Hasyim Krapak melihat Dusun Gemutri belum terjamah oleh ulama, masyarakatnya awam, tidak menjalankan syariat Islam dan masih percaya pada animisme dan dinamisme. Berangkat dari hal tersebut Kiai Hasyim mengutus putranya yakni Mbah As'ari untuk berdakwah dan menyebarkan tarekat Qadiriyah wa Naqsabandiyah.

Kedua, tarekat Qadiriyah wa Naqsabandiyah di Dusun Gemutri membawa peran dalam pembinaan keagamaan warga. Hal yang pertama diajarkan adalah ilmu syariat, setelah warga telah memahami ilmu syariat Mbah Asy'ari mengajarkan pendidikan akhlak dengan mengenalkan tarekat Qadiriyah wa Naqsabandiyah. Amalan-amalan tarekat dan kegiatan keagamaan (yang dibina oleh Tarekat Qadiriyah wa Naqsabandiyah) memberi pengaruh spiritual pada jamaah dan warga dusun, secara umum pengaruh spiritual tersebut antara lain: pendekatan diri kepada Allah, menjadi pribadi yang berakhlak mulia, menjadi pribadi yang tawakkal, pribadi yang sabar dan ridha.

Ketiga, eksistensi tarekat Qadiriyah wa Naqsabandiyah di dalam kesalehan sosial yaitu pengaruh spiritual yang telah didapat pada pengamalan ajaran tarekat dan diaplikasikan pada kehidupan sosial masyarakat Dusun Gemutri. Nilai-nilai kesalehan sosial masyarakat terintegrasi pada kegiatan keagamaan dan sosial, serta perilaku masyarakat Dusun Gemutri. Kegiatan keagaman antara lain: yasinan, mujahadah malam Jumat, pengajian kitab, kasidah, dan ziarah makan. Kemudian kegiatan sosial antara lain, gugur gunung, ronda, rapat warga, iuran idensial, kenduren, sadranan, dan syukuran. Melalui kegiatan-kegiatan tersebut bahwa masyarakat Dusun Gemutri mempunyai kepekaan sosial yang tinggi, warga yang saleh, suka menolong, menyayangi sesama, menghormati sesama, gotong royong dan bermusyawarah untuk mufakat.

\section{Daftar Pustaka}

Abdullah, M. A., \& Abdurahman, D. (2006). Metodologi Penelitian Agama: Pendekatan Multidisipliner. Yogyakarta:
Lembaga Penelitian, UIN Sunan Kalijaga : Kurnia Kalam Semesta.

AF. (2019, Agustus). Wawancara.

Afifuddin, \& Saebani, B. A. (2012). Metodologi Penelitian Kualitatif. Bandung: Pustaka Setia.

Azlan, U. (2018). Pemaknaan Linguistik Barokah pada Kehidupan Ikhwan TQN Suryalaya. LATIFAH, 2(2), 42-54.

Azwar, S. (1998). Metode Penelitian (1 ed.). Yogyakarta: Pustaka Pelajar.

B. (2019, Agustus). Wawancara.

BHH. (2019, Agustus). Wawancara.

Bisri, A. M. (1994). Saleh Ritual, Saleh Sosial. Yogyakarta: DIVA PRESS.

Bruinessen, M. van. (1992). Tarekat Naqsyabandiyah di Indonesia: Survei Historis, Geografis dan Sosiologis. Bandung: Mizan.

BS. (2019, Agustus). Wawancara.

Cecep Zakarias El Bilad. (t.t.). Makna Saleh dan Macam-macamnya. Diambil 22 Mei 2020, dari https://www.nu.or.id/post/read/69774/ma kna-saleh-dan-macam-macamnya

Falah, R. (2016). Membentuk Kesalehan Individual dan Sosial Melalui Konseling Multikultural. KONSELING RELIGI Jurnal Bimbingan Konseling Islam, 7, 163. https://doi.org/10.21043/kr.v7i1.1666

Firdaus, F. (2017). Tarekat Qadariyah Wa Naqsabandiyah: Implikasinya Terhadap Kesalehan Sosial. Al-Adyan: Jurnal Studi Lintas Agama, 12(2), 159-208. https://doi.org/10.24042/ajsla.v12i2.2109

Helmiati. (t.t.). Kesalehan Individual dan Kesalehan Sosial. Diambil 22 Mei 2020, dari Universitas Islam Negeri Sultan Syarif Kasim Riau website: https://uinsuska.ac.id/2015/08/19/meyakini-shalatsebagai-obat-muhammad-syafei-hasan/

Huda, N. (2007). Islam Nusantara: Sejarah Sosial Intelektual Islam di Indonesia. Yogyakarta: Ar-Ruzz Media.

Kaelan. (2010). Metode Penelitian Agama Kualitatif Interdisipliner. Yogyakarta: Paradigma.

Khaerani, I. F. S. R., \& Nurlaen, Y. (2019). Makna Simbolik Zikir Pada Jemaah Tarekat Qadiriyah Naqsabandiyah (Studi Kasus Pada Jemaah Tarekat Naqsabandiyah di Pondok Pesantren Sirnarasa Ciamis). Jurnal Studi Agama dan Masyarakat, 15(2), 87-97. https://doi.org/10.23971/jsam.v15i2.133 1

Koentjaraningrat. (1987). Sejarah Teori Antropologi. Jakarta: Penerbit Universitas Indonesia. 
Madjid, N. (2019). Islam: Doktrin \& Peradaban. Jakarta: Gramedia pustaka utama.

Marzali, A. (2014). Struktural-Fungsionalisme. Antropologi Indonesia, 30(2).

MU. (2019, Agustus). Wawancara.

Mulyati, S., \& Bakhtiar, A. (2005). Mengenal \& Memahami Tarekat-Tarekat Muktabarah di Indonesia. Jakarta: Kencana.

Nihglatunnafi' Ah. (2006). Silsilah Amalan Hati: Ihlas, Tawakkal, Optimis, Takut, Bersyukur, Ridha, Sabar, Interospeksi Diri, Tafakkur, Mahabbah, Taqwa, Wara'. Bandung: Irsyad baitus salam.

Nurcholis, A. (2011). Tasawuf antara Kesalehan Individu dan Dimensi Sosial. TEOSOFI: Jurnal Tasawuf Dan Pemikiran Islam, l(2), 175-195. https://doi.org/10.15642/teosofi.2011.1.2 .175-195

Pustaka, T. B. (2010). Kamus Saku Bahasa Indonesia. Yogyakarta: PT Mizan Publika.

S. Margono. (2005). Metodologi Penelitian Pendidikan. Jakarta: Rineka Cipta.

Sobary, M. (2007). Kesalehan Sosial. Yogyakarta: LKiS Yogyakarta.

Srijanti, S.K, P., \& Pramono, W. (2009). Etika Membangun Masyarakat Islam Modern. Diambil dari //library.fis.uny.ac.id\%2Fopac\%2Findex. php\%3Fp\%3Dshow_detail\%26id\%3D58 07
Sugiyono. (2008). Metode penelitian pendidikan: (Pendekatan kuantitatif, kualitatif dan $R$ \& D). Alfabeta.

Sujuthi, M. (2001). Politik Tarekat Qadiriyah wa Naqsyabandiyah Jombang: Studi Tentang Hubungan Agama, Negara dan Masyarakat. Yogyakarta: Galang Press.

Sukamto. (1999). Kepemimpinan Kiai Dalam Pesantren. Jakarta: LP3ES.

Suyanto, B., \& Sutinah. (2015). Metode Penelitian Sosial: Berbagai Alternatif Pendekatan. Prenada Media.

Syukur, A. (2001). Tasawuf dan Krisis. Yogyakarta: Pustaka Pelajar, diterbitkan bekerjasama dengan IAIN Walisongo Press.

Syukur, H. M. A. (2002). Intelektualisme Tasawuf: Studi Intelektualisme Tasawuf Al-Ghazali. Yogyakarta: Pustaka Pelajar.

US. (2019, Agustus). Wawancara.

Wahid, A., Amin, M. M., \& S. Ahmad, I. (1993). Dialog Pemikiran Islam \& Realitas Empirik. Yogyakarta: Diterbitakan oleh LKPSM NU DIY bekerjasama dengan Pustaka Pelajar Yogyakarta.

Yani, A. (1997). Mutiara Da'wah (kumpulan Artikel Bulletin Da'wah Khairu Ummah). Jakarta: (LPPD) Khairu Ummah. 